Trivent Publishing

(C) The Authors, 2015

Available online at http://trivent-publishing.eu/

Philosophy, Communication, Media sciences Series

Volume Saint Gerard of Cenad: Tradition and Innovation

\title{
Socrates and the Theory of Virtues in the Deliberatio supra hymnum trium puerorum by Gerard of Cenad
}

\author{
Claudiu Mesaroș
}

Department of Philosophy and Communication, Centre for Research in Philosophical Historiography and Philosophy of Imaginary, West University of Timișoara, Romania, claudiu.mesaros@e-uvt.ro

\begin{abstract}
The aim of this paper is to investigate one of the philosophical directions of Gerard of Cenad's Deliberatio, namely, the link between acknowledging Isidore of Seville's suggestion that Socrates was responsible for giving the subject of cardinal virtues to philosophy, in their turn important for the development of Gerard's discourse, and the further development of Gerard's discourse on virtues, more precisely, his identification of the cardinal and theological ones, as in István Bejczy's hypothesis.
\end{abstract}

Keywords: Gerard of Cenad; Socrates; theological virtues; cardinal virtues; medieval philosophy; charisms. 


\section{Introduction}

The Deliberatio supra hymnum triorum puerorum ad Isingrumum liberalem raises essential questions regarding its functioning in the cultural context, philosophical sources and especially the personal way, if any, Gerard relates himself to certain historical figures he often mentions such as Aristotle, Plato, and others. There are many places he mentions and even makes judgments on ancient philosophers and yet we are aware his knowledge on them was only indirect and most probably dependant on Isidore of Seville's Etymologoies (Nemerkényi, 2004). The title of the Deliberatio is disputed as well. At the beginning of Book II Gerard himself makes us expect an "educated deliberation" (eruditam deliberationem), a judgment that should not be trivially criticized (et discurse non potest, quemadmodum nec oportet, examinari inexaminatis taxationibus praecipue ad eruditam deliberationem...). It seems to announce a hermeneutical endeavor but it could as well be a deliberatio in the sense of epichereme. If we are to take Isidore's Etymologies as the main source for Gerard's text, as it it the case, then it is important to note that deliberatio was, for Isidore, a kind of epichereme. Here is what Isidore says at 2.9.7; 16-1 in his Etymologies:

"7. There are two types of inference. First is the enthymeme (enthymema) ... The second is the epichireme (epichirema), a non-rhetorical, broader syllogism. (...) 16. ... epichireme, deriving from inference as broader and more developed than rhetorical syllogisms, distinct in breadth and in length of utterance from logical syllogisms, for which reason it is given to the rhetoricians. This consists of three types: the first, of three parts; the second, of four parts; the third, of five parts. (...) 18. The fivepart type accordingly has five members: first the major premise, second its proof, third the minor premise, fourth its proof, fifth the conclusion. Cicero puts it thus in his art of rhetoric (On Invention 1.9): "If deliberation (deliberatio) and demonstration (demonstratio) are kinds of arguments (causa), they cannot rightly be considered parts of any one kind of argument - for the same thing can be a kind of one thing and part of another, but not a kind and a part of the same thing," and so forth, up to the point where the constituents of this syllogism are concluded." 1

Deliberatio could mean then, as in Cicero's definition taken after Isidore, a broader and more developed form of inference, consisting in five parts: major premise, proof, minor premise, proof, conclusion. Gerard will most probably try to follow Ciceronian structure in his own Deliberatio, which means Gerard's work is an intentional rhetorical structure of syllogistic composition, where each premise is tested before attempting any conclusion. It is obvious that the abundant Biblical quotations play most times this role of proofing different premises in the text; also, massive chunks of text from Isidore of Seville's Etymologies might have the same function most of the times. The text should be able to offer interesting surprises from this regard.

Gerard's sources of education are not clearly known; his early studies in Venice have been polemically disputed especially after Gabriel Silagi's edition of the Deliberatio, ${ }^{2}$ On these grounds, Ronald Witt ${ }^{3}$ argues that no solid evidence of schools in Veneto existed in Gerard's times, although some suppositions might be made since serious stylistic practice can be found in different

\footnotetext{
${ }^{1}$ Stephen Barney, W. J. Lewis, J. A. Beach, Oliver Berghof, The Etymologies of Isidore of Seville (Cambridge: University Press, 2006, 72. From now on we will be referring to the Etymologies in the text, giving only the annotations from this edition and abbreviated as Etym.

${ }^{2}$ Gabriel Silagi, Gerard of Csanád. Deliberatio supra hymnum trium puerorum CCCM 49 (Turnhout: Brepols, 1978).

${ }^{3}$ Ronald G. Witt, The Two Latin Cultures and the Foundation of Renaissance Humanism in Medieval Italy (Cambidge: University Press, 2012), 134-135.
} 
\begin{tabular}{r|r} 
C. Mesaroș & 3
\end{tabular}

compositions of the time. Assuming the realism of the passage in Deliberatio 41 ("In Platone quippe disputationes quondam apud Galliam constitutus quasdam de Deo Hebraeorum confidenter fateor me legisse et de caelestibus animis"), Witt says, ${ }^{4}$ after Silagi, that Gerard encountered Chalcidius's translation of Plato's Timaeus, probably other texts as well, while visiting or living in Francia; presumably, no similar richness and not even sufficient quantity of writing support were available for him afterwards in Hungary (as another presumed realistic note in Delibeatio goes: "Multa dici possunt, sed penuria scriptorum atque membranorum non patitur." - Book VIII, 177). ${ }^{5}$

As the influence of Denis the Areopagyte is concerned, it is clear that he had direct access to the Latin translation of the Corpus Areopagiticum. ${ }^{6}$ The cult of Denis had spread as far as England before the eleventh century; ${ }^{7}$ on the continent, a more lively tradition of copying and studying Denis and Eriugena had developed much before Gerard and therefore it was not uncommon during his time to use Denis in Eriugena's translation as a preferred source for biblical interpretation.

\section{Why Christians should praise Socrates}

Gerard mentions Socrates only once, at the beginning of Book $I V$, in a very dense philosophical passage, together with Gorgias, Aristotle, Hermagoras, Tulius, Quintilianus, Thales of Miletus, Varro, and Plato. The passage discusses one of the most constant explicit philosophical subjects of Deliberatio, that is, the relation between the wisdom of academic (pagan) philosophers and the wisdom of uneducated practitioners of Christian virtues, having Saint Apostle Peter as supreme model. Book IV starts with a digression regarding the method of discourse, asking whether we should prefer straight and direct investigation of the text to be interpreted according to its internal order and disposition, or we should rather prefer amplifications and digressions of style. Gerard will continue using a digressive style, this fourth book probably being the richest in philosophical subjects.

He will discuss about pagan philosophers' merits as a figure of deliberatio in the Ciceronian sense discussed above, that is, by establishing a proof for one of his premises. First he makes some clarifications on the relational meaning of benedictio and laus, as they appear both in Dan. 3,6, with reference to the Divine powers ("Benedicite - ait - omnes virtutes Domini Domino") and in the Psalms of David, which are called laudis; Gerard admits their similitude ("vera benedictio, id est eterna laus") and will consequently be driven to the necessary question regarding whom we can praise. Gerard quotes the sacred text in Romans 12.14, which says: "Benedicite persequentibus vos, benedicite, et nolite maledicere" and asks whether we are to be praising creatures of God even if some of them persecute us. The answer seems to be affirmative in some way, to the extent that we are not praising humans as such, according to their corrupted and mortal nature (tantum mortales) but their beautiful spirits ("pulchra ingenia").

This discussion is more meaningful to the extent that Gerard is not simply taking here the concept laus from the Etymologies of Isidore (2.4.5.: "Demonstrative argument ... has two species: laus and

\footnotetext{
${ }^{4}$ Ibidem, 135.

${ }^{5}$ We will be referring to Gerard's text by the number of the Liber from now on (Book I to Book VIII), in the text. The text is that of Gabriel Silagi, Gerard of Csanád, corroborated with the edition: Ignatius Batthyány, Sancti Gerardi episcopi Chanadiensis scripta et acta hactenus inedita cum serie episcoporum Chanadiensium. (Albae-Carolinae. 1790).

${ }^{6}$ More on this in Elöd Nemerkényi, Latin Classics in Medieval Hungary $11^{\text {th }}$ Century. (Budapest: Central European University Press, 2004), 73-156.

${ }^{7}$ Luscombe, "The reception of the writings of Denis the pseudo-Areopagite", in Tradition and Change: Essays in Honour of Marjorie Chibnall. (ed. D. Greenway, Ch. Holdsworth, J. Sayers, Cambridge: Cambridge University Press, 1985, 115-144), 125-6.
} 
\begin{tabular}{r|r} 
C. Mesaroș & 4
\end{tabular}

vituperatio"), but is bringing the theological relation of laus-benedictio to help his purpose. In other terms, Gerard surely had the description of Isidore in front of his eyes but considered important to clarify the theological laus in turn.

In the same Book IV he will say that we must praise (laus) pagan philosophers for their spirit (ingenium) and merit (iure) as divine creations, as every human person was gifted by God: "Laudare itaque antiquorum ingenia et iure debemus;" still, they must not be blessed. Benedictio (blessing) is not suited for them; we should not bless (and here Gerard is using lists from Isidorus of Seville's Eymologies, 2) Gorgias, Aristotle, Hermagoras, Tullius, and Quintilianus, the inventors and translators of rhetoric. Should we rather bless Thales of Miletus, the first researcher of nature, or Varo, for distinguishing the two noble disciplines of dialectic and rhetoric, showing their finality? Should we bless Plato, for dividing Physics in four (arithmetic, geometry, music and astronomy)? These rhetorical questions impose severe limits: for all their merits, pagan philosophers must only be praised. This is the place when Socrates is mentioned for his own specific and important merits, namely, for instituting moral dispute in searching for the good life (bene vivendi) and especially the four cardinal virtues ("animae virtutibus"): prudence, fortitude, temperance, and justice (prudentia, fortitudine, temperantia, iustitia).

\section{Socrates and the divisions of Philosophy in Gerard}

Logic was added added to Ethics, for the reason of investigating the rationality of moral discourse, and was then divided in Dialectic and Rhetoric. Thus the three divisions of Philosophy are, following Isidore of Seville's Etymologties 2.24.3: Physics, Ethics and Logic, all grounded, Gerard admits, on the Scriptures. The Genesis and The Ecclesiast are physical, The Proverbs is ethical and The Epithalamium (Canticum Canticorum) is logical (see Etymologies, 2.24.8), in the sense of rhetoric, just discussed, as Isidore says (Etym. 1.39.18) that "epithalamiums (epithalamium) are wedding songs, which are sung by rhetoricians in honour of the bride and groom."

As the divisions of philosophy are concerned, Gerard follows Isidore and associates Thales, the first physics investigator, with Socrates, inventor of ethics, and Varro, as seen above, for his definition of Logic. ${ }^{8}$ In fact, Gerard is discussing logic twice, quoting two different passages from Isidore. First, he quotes Etymologies 2.23.1-2 when he says that Varro defined rhetoric and dialectic: "et Varro, qui nobiles geminas disciplinas definiendo sic distinguere dignatus est dicens, quod altera ab altera in manu hominis pugnus adstrictus et palma distensa. Una verba contrahens, alia distendens. Una ad disserendum acutior, altera ad ea, quae nititur instruenda, facundior. Una ad coessentes, alia ad forenses procedit. Quarum una studiosos requirit rarissimos, altera facundissimos populous." Then a few lines lower he quotes Etymologies 2.24.7 when saying that the twin disciplines of dialectic and rhetoric were added to Socrates" ethics: "subiungens logicam, quae rationalis vocatur, per quam discursis rerum morumque causis uim earum rationabiliter perscrutatus dividens eam in supra praedictas geminas disciplinas, dialecticam utique et rhetoricam." Merits for logic are shared in a vague manner between Plato and Varro, whereas Thales and Socrates have priority in natural science respectively ethics, as Gerard is able to learn from Isidore. Nevertheless, it is important to note that Gerard is not commenting nor criticizing Isidore but rather takes him as unique and granted information source.

\footnotetext{
${ }^{8}$ David Lindberg, The Beginnings of Western Science: The European Scientific Tradition in Philosophical, Religious, and Institutional Context, Prehistory to A.D. 1450 (Chicago: University of Chicago Press, 1992 ), 137. See also: Etym., 2.23.
} 
\begin{tabular}{r|l} 
C. Mesaroș & 5
\end{tabular}

\section{Socrates, cardinal and theological virtues}

Although Socrates is only mentioned once in the Deliberatio, the context plays a crucial role in identifying some biases and hermeneutical directions for Gerard's text in general. As seen before, Gerard considers Socrates as the father of ethics and especially the originator of the cardinal virtues theory. The fragment reads as follows: "tuusque Socrates, ad corrigendos mores componendos primus instituens et ad omne studium eius bene vivendi disputationem perducens eamque in quattuor virtutibus animae dividens, nimirum prudentia, iustitia, fortitudine, temperantia, subiungens logicam, quae rationalis vocatur, per quam discursis rerum morumque causis uim earum rationabiliter perscrutatus dividens eam in supra praedictas geminas disciplinas, dialecticam utique et rhetoricam, in quibus tribus generibus philosophiae etiam divina eloquia tota a peritis constare videntur" (Deliberatio, IV).

The text is taken from Isidore again (Etym., 2.24.5-6), but only in part. Gerardus is not copying the meaning of cardinal virtues as in Isidore's text but we may suppose he is assuming them. In the Etymologies they are described as follows: "6. Prudence (prudentia) has to do with how the bad is distinguished from the good in affairs. Fortitude (fortitudo), how adversity may be borne with equanimity. Temperance (temperantia), how passion and the desire for things may be reined in. Justice (iustitia), how to each is distributed his own by right judging."

The most interesting fact about these passages is not what Gerard does to Socrates, as he is actually not doing anything besides taking notes from Isidore, but the way he associates Socrates with the cardinal virtues and, via cardinal, to the theological virtues. Gerard takes part to a tradition, starting with the eleventh century, of associating cardinal virtues with theological virtues in a manner that is entirely new. Before the eighth century, in the works of Ambrose, Jerome and Augustine, it was assumed that faith brings virtues with it and therefore cardinal virtues were secondary in respect to the Christian faith; on the contrary, early medieval thinkers such as Peter Damian and John of Fecamp, got to re-evaluate this ancient association and started praying to God to confer both cardinal and theological virtues upon naming God largitor et conseruator uirtutum, urging for the need to live by the cardinal virtues in order to receive full faith and grace from God. ${ }^{9}$

Subscribing to this re-discovery of ancient association, Gerard of Cenad and his contemporary John of Fruttuaria (or Iohannes Homo Dei, +1049) assume the cardinal virtues and theological virtues as similarly essential for Christians. In his De ordine vitae, Iohannes defines virtues directly according to Isidore of Seville's De differentiis, then explains that the four cardinal virtues are primary in our instruction and must be taught in adolescence, augmented in young adulthood and perfected at a mature age. They are called "weapons" or "chariot of the four virtues," that must be well steered ("bene rege hanc quadrigam virtutum, et sede in ea firmus, ut isto vehiculo vehi altius") by the soldier of faith so that finally he will enter God's three-roomed house and receive the theological virtues. Iohannes calls cardinal virtues intermediary (virtutes mediae), because they can be used well or badly, therefore are corruptible, but still essential for our development as they prepare humans to receive the theological virtues: faith, hope and charity. ${ }^{10}$ Cardinal virtues became usually associated with theological virtues in later authors, such as the next generation's Guibert of Nogent (1055-1125/6),

\footnotetext{
${ }^{9}$ István Bejczy, The Cardinal Virtues in the Middle Ages: A Study in Moral Thought from the Fourth to the Fourteenth Century (Leiden: Brill, 2011), 44; 47.

${ }^{10}$ Ibidem, 45-46.
} 
C. Mesaroș
Socrates and theory of virtues in the Deliberatio supra hymnum trium puerorum by Gerard of Cenad

who, based on the model of Gregory, presents the four cardinal virtues as essential spiritual qualities that make humans similar to God by destroying sins. ${ }^{11}$

Gerard of Cenad wrote his Deliberatio during the approximately same time with Iohannes Homo Dei and we find many similarities between the two. The most important resemblance is the unification of the cardinal virtues (prudence, fortitude, temperance, and justice) with theological virtues (faith, hope, and charity) under one single edifice and arguing in different ways for some kind of efficiency of cardinal virtues: as long as we cultivate our "chariot" of four, it will transform our condition and turn us into saints. Therefore, the claim goes, it is the cardinal virtues that bring about the theological virtues and not vice-versa, as the simple but virtuous life is a condition for spiritual ascension.

The fourth book of the Deliberatio is dedicated to discussing the meaning of virtus, as the last sentence of the third Book announces (de virtutibus in quarta denuntiatione disputare adoriamur), but we will discuss separately the multiple usages of the word "virtus" in Gerard.

\section{A. Simple life as a virtue}

In Book I, Gerard interprets the biblical three young boys as signifying all the persons who offer help to the weaker, live a simple life like the Apostles and decorate themselves with the acts of virtues: "et simplicem vitam expetunt, ut apostoli fecerunt, virtutum decori redduntur operibus" (Deliberatio, Book I). There are many more places in the text where Gerard considers the simple life of the uneducated as virtuous in itself and able to raise the subject to a superior understanding of God.

Every human, we read again in the Book III, who abandons vices and cupidity for the virtuous deeds, must be named celestial and not terrestrial because they truly live a celestial life, even if they have a corrupt body that tends to tear them down: "Omnes, qui relictis vitiis et cupiditatibus ad infernos animas mergentibus in virtutum actionibus versantur unici Domini nostri sequentes exemplum, caelestes et non terreni dicendi, in caelo vero, non in mundo, quamquam terrena aggraventur habitatione corpore adstricti corruptivo" (Book III). They are the true servants of God (in Book VIII: "servi Dei, qui se regit ad virtutes et non ad vitia"). Such simple men are elected by God to receive illumination. It is the case of Peter for example. St. Peter is the master model for the simple practitioner whose faith is built on cardinal virtues and finally receives understanding of divine wisdom.

Along with Saint Peter, Moses is another figure who was empowered by God. In the Vulgata, he is said to have had a face of horn ("cornutus in facie"), and therefore the entire church is seen through Moses' horns in Book VIII, being given virtue and power in order to frighten its enemies ("Cornua virtutem et potentiam demonstrant;" “cornua virtute divina," "Exaltabuntur cornua iusti"). In David's house, God erected horns ("In hac quippe domo cornu erexit") and so by His virtue it was enlarged to comprise the whole world ("dum sua virtute et potentia per totum mundum usquequaque illam dilatavit"). In consequence, just like in the later case of Peter, God will erect His church on Moses: "Si exaltatur ecclesiae cornu, id est virtus sibi data a Christo essendi, ubi Christus est" (Book VIII).

\section{B. Virtue as power to share the divine word with others}

The hermeneutic of the sacred text presupposes that there is an ability of the interpreter to share the meaning of the text with the others. The interpreter's act is blessed by God and the reader himself is one of the perfectores, forerunners of faith, a bishop. In Book III, we encounter a paragraph where

\footnotetext{
${ }^{11}$ Ibidem, 43.
} 


\section{Mesaroș 7 \\ Socrates and theory of virtues in the Deliberatio supra hymnum trium puerorum by Gerard of Cenad}

Gerard says that, due to the ignorance of the mortals, there are many who speak successfully to the crowds although their word is not according to the divine wisdom. At the same time, the real wisdom is hidden among the saints. Still, we can take distance from the teachings of these tricky "stulti sapientes" and share wisdom with the many according to some intrinsic virtue "circa virtutem impertiamur" (Book III), and, of course, according to the mystery of the Divine power.

The prologue to Book VI, announces that we are expected to understand the core of the song that is not captured neither in literary forms nor in the philosophers' medium [terms], but has a virtue of its own ("ubique diffusum in toto enim et a toto, ipsumque totum, medium vero, a quo prima et media et ultima, longe a philosophorum mediis, quamquam sua virtute haec"). This virtue rests on the Spirit which is the aim of faith; there is a beautiful phrase that could serve as a motto to the present paragraph as well: "Fides non quaerit tumorem eloquii, sed spiritus virtutem - Faith does not search for the flourishing of eloquence but to the virtue of spirit" (Book VI). Gerard is seeing himself as an authority obliged to transmit the sacred word and this is how he takes his hermeneutical endeavour on the Song of the Three Young Boys: according to the virtue ("circa virtutem" - Book VI). And, when ending Book VII, he concludes once more: "I have not followed the murmurs of the orators nor the deliriums of the rhetoricians, who merely imitate the beauty of the word but not the power of the mysteries" (Book VII). In the same book, the mysteries are called "gifts given to the Church" ("virtutum inenarrabilium Dei munera ecclesiae condonata" - Book VII).

\section{Virtue as divine power: creation, order and restoration}

Another sense of virtue regards the divine power, most of the times with the meaning of creative power. We encounter interesting occurrences at the end of Book I when Gerard describes the heresies, once more following Isidore of Seville's Etym. 8.5. These occurrences are not directly linked to our subject as Gerard, after Isidore, is using the concepts with disdain and almost non-referentially. For instance, a "virtue" meaning "creative power" appears in the sentence about the Simonians (Simoniani), saying that the creatures come from a superior power not from God (creaturam non a Deo, sed a virtute quadam superna creatam); this occurrence equals virtue with creative power, hard to link to the cardinal virtues for the moment. A few lines below we read that according to Ophites, the serpent brought in Heaven the knowledge of virtue ("in paradiso induxisse virtutis cognitionem"). Here the concept is strangely different; it seems to be rather close to the virtu of the Renaissance Humanists, a term accompanied by the anthropocentric idea of self-sufficient trust in one's qualities: Melchizedechians say that Melchisedec was not a human being, but a Virtue (i.e. "a member of the angelic order of Virtues," as in Etym 8.5.17).

God's virtus is present in the entire creation and can be seen within it from the very beginning of the world (see Romans, 1,20 quoted by Gerard in the same Book VI: "Invisibilia ipsius a creatura mundi per ea, quae facta sunt, intellecta conspiciuntur, sempiterna quoque eius virtus et sapientia, ut sint inexcusabiles," but also Romans 15, 17-25, 29 several lines below), so that the interpreter of the stars and saints and all creatures must identify the meanings according primarily to God's mind apart from human creativeness (,, divinae aptanda animi virtute, non humani ingenii deliberatione”- Book VI).

The divine power of creation can be present in creatures as well. A significant occurrence in Book II says that the three young boys arrived to such level of virtue ("ad tantam virtutum devenerunt, ut visibilia et invisibilia omnia uno vocis articulo pariter conglomerarent ad benedicendum superbenedicendum") that by a single vocal call they brought together everything that is seen and 
\begin{tabular}{r|r} 
C. Mesaroș & 8
\end{tabular}

unseen in the created realm in order to praise by super-praising. This gesture is the same kind as creative power since the entire nature is transformed into a praying entity.

As a consequence, creative virtue may be seen as the multiplication and order of creation. Here, in Book II but also in Books VI and VII, Gerard quotes a biblical passage from 1 Corinthians 12.28 (see as well 12.10) where it is stated that God organized the hierarchy in Church as follows: first there are the Apostles, then the Prophets, Doctors (doctores), Virtues (Virtutes, or Miracles), then gifts of healing (gratias curationum), then the service of helping the weak (opitulationes), then administration of goods (gubernationes), and ultimately the diversity (or interpretation) of tongues (genera linguarum) and so on (see esp. Meyer's commentaries on this). ${ }^{12}$ This is one of the most essential subjects regarding the hierarchy of church. Virtue, within the present context, is usually interpreted as the power of miracles gifted by Christ (as Christ is the wisdom and virtue of God - "Christus ... ipse Dei virtus et sapientia," in Book VII) to certain members of the Church, for it is Christ who has given to the Patriarchs the wings of virtue, and with these wings John flew above everything as he revealed the mystery of the Deity ("In ipso enim [Christus] virtutum omnium pennae" and "Ipse dedit pennas has patriarchis, ipse prophetis, ipse apostolis et ceteris, qui in caelestibus gloriantur. His pennis volavit supra omnia Ioannes, quando expressit deitatis archanum" - Book VII).

Similarly, the creative virtue is described in Book VIII as a power by which supernatural Physics is introduced by God into the world, and the power which demonstrated the inestimable Ethics and supernatural Logic ("Potenti virtute insinuatur supernaturalis physica, demonstratur inaestimabilis ethica et logica principalis"); by this virtue God is revealed as the source of everything, that surpasses all, and without whom philosophers speak empty words.

Again, in Book VIII, Gerard is speaking about the great power that the Holy Scriptures have, so great that nobody can understand it completely ("Denique quantae virtutis divina sit scriptura, paene a paucis, immo a nullo comprehendi potest"); then: "truth masters everything, Divine power shines everywhere" etc ("Ubique in eis veritas regnat, ubique divina virtus irradiat, ubique panduntur humano generi profutura"), and again: "the Scripture is full of all the power and word that does not fall empty" ("Lectio cuncta virtutum est verbum non inaniter cadens").

Another meaning is the power of God as restorative. At the beginning of Book V Gerard cites the biblical quote "virtus Dei et sapientia" from 1 Corinthians 1,24, to illustrate the supreme power of God to restore all the creation in Heaven: "Cum exaltatus fuero a terra omnia traham ad me ipsum." By this we understand that, says Gerard, the Church has been chosen by Christ. Restoration is visually represented by the episode when Christcleans the disciple's feet: a miracle sacrament destined to all nations, a power which saves the world from the claws of death ("cuius virtute est salvatus totus mundus de manu mortis" - Book VII).

\section{The three levels of virtue in Book IV}

Book IV of the Deliberatio is dedicated to discussing the concept of virtue (virtu) according to the biblical song and it starts with the virtutes Domini that are said to be praising God ("Benedicite omnes virtutes Domini Domino") and belong to the Angels that stay firm in their positions (per quas omnes optime remanentes). But Gerard says the celestial powers have been treated by the Areopagyte and is not insisting on them ("virtutes" names, to this extent, one of the Areopagytic hierarchies: "throni et dominationes, quemadmodum angeli et archangeli, virtutes vero principatus ac potestates et cherubim et seraphim" - in Book VIII). Rather, he passes on to the virtues in the world. Still, several places of

\footnotetext{
${ }^{12}$ A. W. Meyer, Critical and Exegetical Commentary on the New Testament (T. Clark, Funk \& Wagnalls, 1884).
} 
\begin{tabular}{r|r} 
C. Mesaroș & 9
\end{tabular}

Biblical nature inspire Gerard to meditate on this greatness incompatible with human powers, like in these two beautiful sentences in Book VI: "O virtus, o potentia Dei in hominibus magna et inaestimabilis dicenda"; "Non enim a mundanis meditari possunt insignia perfectorum, nec illorum fortia sequi" or by quoting that the virtue of Christ has broken gold and silver, brass and iron and skull ("et solita virtute fretus aurum et argentum, aes et ferrum et testam comminuit" - Book VI).

A special and intricate passage at the end of Book VI meditates on the intelligibles as powers or incorporeal virtues: intelligible natures were created factually immortal and have their permanence according to God's will ("Ergo intellegibilia proprie existentia ut immortalia facta et aeterna sicut infinita voluntate Dei permanentia oportet dicere"), therefore they are intermediary: eternal according to the Divine will, non-eternal as they have a created nature ("quae et aeterna, incorporales virtutes a Deo conditas, non tamen coaeternas Deo"). Gerard says that these intermediary natures or virtues are, for instance, heaven and stars, as they are bodily but at the same time more subtle ("subtioliora"), and they were created before light was created.

We turn back to Book IV in order to encounter the second level of universal virtues. Starting from the phrase "Benedicite omnes virtutes Domini Domino," Gerard observes an implicit division: whereas some virtues do not belong to God and do not bless Him, some other virtues bless God ("quaedam virtutes, ut audisti, Domini, quae Domino benedicunt, quaedam, quae non"). There are negative powers, virtues that have risen against God and against Divine justice ("contrariae sint virtutes et contra iustitiam rebellantes"), and they cannot be defeated without God's weapons ("armatura Dei indui monet. Sine hoc enim contrariae fortitudines non prostrantur").

The powers of faithful are multiple: first, those who have spread the Evangels ("evangelium denuntiaverunt"), namely, the apostles and their followers, who have fortified their faith and became stronger than evil; they are not Angels, not learned but simple fishermen who strengthened their power to such level that they subjugated the world ("non eruditos, sed piscatores, non dialecticos, sed simplices, quorum vestigio totus orbis subiugatus"). This kind of virtue is the power of simple life, able to turn people into philosophers and saints. The saint-philosopher is able to reach theoretical wisdom starting from practical virtues, a state of mind compared in Book II with supersapiens, the wisdom of St. Peter, who is taken by Gerard as paradigm for practical philosophers who are therefore named "people of Peter:" they practice Christian virtue and therefore reach a superior condition ("segregari in splendoribus reformativis"). Saints have "wings of virtue" to ascend to the heights ("sancti intellegendi, qui virtutum pennis ad alta conscendunt"). In Book IV, Gerard says: "He who received the potency (qui accepit potestatem caeli) of Heaven and the mastership of the entire world after God knew better how to catch fish than how to read. (...) But after they were gifted by the Holy Spirit, they were able to transcend the whole wisdom of deadly philosophers and became more skilful and learned than all" (Book IV).

However, suffering is not uncommon in the life of the apostles and their followers, therefore they can face difficult endeavours to the extent that their power or virtue be tested to the limit. In Book V there is a quote from 2 Cor. 1, 8-10: "supra modum gravati sumus supra virtutem ita, ut taederet nos etiam vivere" ("we were pressed out of measure, above strength, insomuch that we despaired even of life" $" 13$ ).

The second divine power is a gift and belongs to the followers of the Apostles ("omnes horum vestigia imitantes"): the noblest testifiers, the sanctissimos perfectores and all the divine orders and those who fought against heresies, those who suffered and got imprisoned or crucified for Christ, stepping against evil. All these men and women are vessels (vasis fictilibus) of Christ and their power

\footnotetext{
${ }^{13}$ Cf. King James Version.
} 
is supernatural, mysterious and together with all the powers of this second kind form the Church: in Book VI Gerard says that the church is ornated with virtues that are unknown ("multis virtutibus a quibuspiam incognitis"), or that the doctrines together with the virtuous actions enlighten God's family ("virtutumque operum lampadibus dominicam familiam omni tempore").

Returning to Book IV, we observe that those who rely on natural virtues or human powers cannot ascend by themselves to such heights: neither Darius, nor Xerxes, nor Arthaxerxes, Ochus Arthaxerxes, Alexander Macedo, Ptolemaeus, Ptolemaeus Philadelphus, Ptolemaeus Evergetes, etc, could ever become vessels of Christ. Pagan philosophers were far from such gift: Platonists, Stoics, Academics, Peripatetics, Epicureans, Gymnosophists, according to a list given by Gerard after Etymologies 8.6, were, at their turn, not gifted to be Christ's vessels as only the humble, silent and trembling ones were targeted ("humiles et quieti et trementes" - Book IV). The earthly philosophers were in error, especially those who reduced the power of God to atoms, to elements or to an infinite series ("dixerunt virtutem Dei in atomis, et mundum non finiendum praesentem, Deum verum de quattuor elementis factum et orbem divina potentia" - Book VIII). Nevertheless, the entire creation is concatenated with the Divine in one single strong unity called "divina societas" (virtutum concatenationem, qua constringitur divina societas" - Book VII).

Third, there are the evil powers (diabolicae virtutes) of several kinds. One of them is heretics, those who have separated themselves from God's unity of the Church ("virtutum concatenationem ... abnuunt" - Book VI) and have fallen apart. Some of these are already defeated, such as Eunomius or Arius, but they are still called diabolical powers because they have the intention to weaken the power of the Church and therefore fight against it with the support of the Antichrist: beasts that, when heard of, we understand devil or Antichrist, who is served by all, who desire flesh ("Bestiam, quam audis, diabolum sive Antichristum intellege, cui serviunt omnes, qui carnis desiderium”- Book IV).

Another kind of evil power refers to fallen angels, as it is said in Book VI: "mind wants to know about the others, like there are stars other than those in the skies, as we have said about the waters and powers" ("ut de aquis in superioribus et virtutibus"). This perverted power or virtue appears to be caused by the rejection or separation from the concatenation of the Divine virtues, a separation that has been effectuated by the very power of the Holy Spirit ("Spiritu, cuius virtute ipse proiectus est" Book VIII). Men of evil powers are continuously tormented by the evil "spiritus procellarum" (Book VIII, "windstorms"), that is, the "impetus omnium vitiorum" (attacks of the vices), raisers wars against the virtuous.

\section{E. Cardinal virtues or the power of nature to ascend to the Divine}

In order to be able to take part in the prayer, natural elements must have some power to respond to the three young boys' chant. Human beings, as well, have a natural power to ascend to God in certain conditions. However, be it natural elements or human nature, they can be recognized as functional cardinal virtues, to say so, only within the Church. Perhaps one of the most suggestive passages sustaining this idea can be found in the middle of Book V, where Gerard explains the natural powers in terms of sun, moon and Church, starting from the commentary of the verse in Dan, 3,62: "Benedicite sol et luna."

The text goes like this: "Quemadmodum luna ex magnitudine mense, quae nunc bicornis, nunc sectilis, nunc media, nunc plena videtur ad eadem denuo tendens. Est itaque ecclesia bicornis gemina dilectione, est sectilis utriusque testamenti eruditione, est dimidia, quia adhuc solius in fide nititur et spe. Erit autem plena, quando erit Deus omnia in omnibus. Efficitur autem iterum de plena dimidia et de dimidia sectilis, demumque bicornis, dum descendit imbecillibus membris suis ad ea, quae istius 
C. Mesaroș
Socrates and theory of virtues in the Deliberatio supra hymnum trium puerorum by Gerard of Cenad

mundi sunt necessaria, sine quibus non subsistit sui innumerositas, providens unicuique circa mandatum" (Book V).

The symbolism of sun and moon reproduces the relation between the Apostolic teaching and the Church: the moon receives light from the sun just as the Church is illuminated by the sacred revealed word. As well, the Church is dynamic in its extension, sometimes being smaller due to those who choose to serve Satan. Full will be the Church, Gerard says, when God will be everything in all (Deus omnia in omnibus). There are seven moon magnitude phases, according to the quantity of light and to the increase respectively decrease of light, as in Isidore's Etymologies 3.54: (1) The new moon with two horns (bicornis), ascending, and the Church has two horns due to the twin love (gemina dilectione); (2) the quarter moon (sectilis), ascending: the Church is foursome due to the teaching of the each testaments; (3) the half moon (dimidia), ascending, because symbolically the Church is grounded in faith and hope only (in fide nititur et spe); (4) the full moon (plena), and descending, it is the plenary Church symbolizing the end of time (quando erit Deus omnia in omnibus); (5) the half moon, descending, then the (6) quarter moon, descending again, and finally, (7) the new moon, are symbols for the descending Church, that is, the church that knees and helps the weaker, without whom it could not subsist ("descendit imbecillibus membris suis ad ea, quae istius mundi sunt necessaria, sine quibus non subsistit sui innumerositas"). Immediately, Gerard says that the first four symbols are the cardinal virtues predicated by the Apostle Paul ("virtutes principales quattuor"), the next two signify the twin testaments, and the last, charity (caritas), is the ornament of the sons and daughters of the Church. Another symbolism associated to the moon's phases represents the seven gifts of the Church ("septem divinissima dona"): (1) Patriarchs, (2) Prophets (3) Apostles (4) Evangelists, and after them there is no diminishing. Still, the full moon (4) may represent again the apostles and martyrs, and then (5) the diminishing half are the Confessors and the Virgins, then (6) the descending quarters represents the fighters, and, ultimately, the (7) final new moon with two horns are the Penitents.

On this ground, Gerard attempts to explain why the cardinal virtues ("virtutes principales") have such a strong role together with the theological virtues: their symbolic powers are linked in a reciprocal interdependence, so that the natural virtue of the Apostles depends on the real light of Heaven which cannot be compared to the natural light ("Apparente luce vera cum virtute et maiestate sua omnia caelorum obscurabuntur luminaria", and again several lines below: "si sol in virtute sua resplendens"). Without it, humans fall and their virtue fades, as it happened to Origene and others. The symbolic meaning of the eclipse is this: the sacred word ceases to enlighten humans during critical times, for instance when humans are do not have the dignity to assist in a divine event like Christ' death ("ut Christo in crucem ascendente haec se soli obbiceret").

Doctors of the Church may as well be obliterated by an eclipse of the sacred truth, but the crowds they address to become subject to this darkening as well. There is no greater bitterness for a doctor than the lack of control over the students ("Quid doctori amarius subditis inordinatis"). Therefore, a doctor should be preoccupied with the practice of the sacred discipline at the school of the sacred virtues ("in schola virtutum sacram exerceat disciplinam").

There are still several other places where Gerard is speaking about this sense of virtue, such as in Book II, where we read: "Hoc autem de angelis, quod amodo ad caelos circa virtutem perueniendum" (this was said about the angels so that we may arrive at the heavens according to our own virtues). This natural or intrinsic power to ascend to God is our necessary resource for engaging onto the redemption path; not sufficient, still, since theological virtues must be added to it, but nevertheless, sine qua non. 


\section{\begin{tabular}{l|l} 
C. Mesaroș & 12
\end{tabular} \\ Socrates and theory of virtues in the Deliberatio supra hymnum trium puerorum by Gerard of Cenad}

In Book III, Gerard will have a generous introduction to heterodox philosophies. Pagan and nonChristian philosophers are in their turn subject to such power, even when they lived during the Christian era. Tychonius was one of the most learned among Donatists ("inter suos quondam doctissimus") but still worth praising for his seven rules of interpretation, which Gerard extracts from Bede's interpretation to the Book of Revelation. Therefore Tychonius, even if a Donatist and therefore blasphemous, must be embraced ("quanquam Donatista nimis amplectendus in istiusmodi regulis atque ceteris a perfectoribus correctis"), as they apply to the entire Scripture, but it is virtue, namely, one of the cardinal virtues, that may allow us to observe such connections ("in omni canonica scriptura et praecipue prophetica vigere si prudens lector accesserit"). Bede himself, the divine priest and perfect healer, says Gerard, praised Tychonius for his ingenium and by imitating him in part he could become a model in Christian virtues ("eiusque imitator, ex parte ipso referente vestigium, qui virtutum in Christi ecclesia est cunctis factus exemplar" - Book III); many other ancient authors followed Tychonius and only time and forgetting obliterated him.

It is God himself who calls humans to respond with their natural virtues to God's challenge, as it was the case with Moses. One of the most powerful passages in Gerard's Deliberatio reads that we must obey our mind to heretic writings sometimes, after the model of the chosen people when ordered to take Egyptians' golden and silver vessels: "Verum tantum est nobis nonnumquam mortalium ac seducentium accommodare animum lectionibus, quantum extitit Dei populo iubente Domino per Moysen sacrum vasa argentea et aurea mutuo accipere Aegyptiorum" (Book III).

It may be important to note that this Biblical allegory makes the whole difference for understanding Gerard's meaning of nature and natural powers: within creation there are good things and bad things, good fish and bad fish, clean animals and unclean beasts ("Sunt quippe pisces boni, sunt et mali, sunt animalia munda, sunt et inmunda. Corvus extra arcam, columba in eadem perhibetur" - Book III): it is gold and silver everywhere and therefore nothing should be wasted.

This human natural power to ascend to God corresponds to the similar force every natural creature has to participate to the redemption. In the third Book Gerard explains why the three young boys summon the waters among the natural powers to praise God. It is a long and significant passage where Gerard speaks more about virtue: „Benedicite - ait - aquae omnes, quae super celos sunt, Domino; benedicite omnes virtutes Domini Domino. Aquas quidem supra caelos esse non solum humani, sed etiam divini tradunt libri. (...) Philosophi vero saeculi solis ignem dicunt aqua nutriri et a contrario elemento virtutem luminis et caloris accipere. Unde saepissime rorans et madidus conspicitur a mortalibus" (Book III).

Here, Gerard starts interpreting from Dan. 3, 60-61, the meaning of summoning waters above the skies to the prayer, and concludes that mundane philosophers did see in waters only natural powers of heat and light received from the sun and from the contrary element (Etym., 3,49). But philosophers did not see that there are two kinds of waters, the waters above the skies ("omnes aquae quae super caelos sunt") and the earthly waters. The summoning for prayer seems to be addressed to the superior waters: "Ergo quae inferius sunt, vacant, superius quae sunt, insistunt circa hortamentum" (Book III), for the natural waters share the fallen status of the corrupted angels ("quae non supra celum sunt, ruentes demonstrare figurative vult recitatio angelos"). Nevertheless, as the superior waters never ceased to take part in the celestial angelic prayer, it is necessary that the whole creature, including natural waters, is the object of calling: "Ac per hoc non absurdum dicendum ad illos sub typo aquarum hortamentum factum." Natural elements, then, have a "power" (in the sense of virtue) to take part to the prayer.

The element of water has allegorical meanings throughout the Scriptures as well. A few paragraphs below Gerard says that, according to the Revelation (17.1), waters signify peoples and nations and 
languages ("ubi meretrix sedet, populi sunt et gentes et linguae"), but this only confirms what has already been said because theology methodologically relies on the reciprocal signification and substitution of things ("Consuetudo theologiae inolevit quaedam pro quibusdam et pro aliis alia ponere"- Book III).

In Book VI, Gerard offers a long discussion about gems, with similar meanings for virtue: sardonyx is varied just as the virtues of Christ, the topaz has many colours to signify the virtues of all saints, the chrysopraze is golden and green, meaning the wisdom and the virtue of justice, the chrysolite is golden and sparks its virtues towards everybody close to it etc.

\section{$F$. The arch of seven virtues}

Much of the Book VIII is dedicated to the virtues, especially to the discussion of the three Church virtues and then the four cardinal virtues, which he actually names pure virtues or spirits or charities, respectively the four "wings" of the soul, or powers. There is a fragment in Book VIII which says that there are some virtues that humans courageously follow to strengthen themselves and become one with God ("Virtutes nimirum, quibus cum Deo unus efficitur homo"). Sometimes these virtues are called spirits ("in sacris dictis virtutes consuevit demonstrare nonnumquam per vocabulum spirituum"), and it is said that God rests on the wings of winds, and that they are the powers of our soul ("virtutes animarum volunt nostrates"), "according to Pope Gregorius."

This fragment of Book VIII allows a functional comparison between cardinal and theological virtues as described by Gerard according to Isidore's Etymologies 13. As virtues are compared to winds, Gerard says that the principal virtue alias winds are four in number (Subsolanus, Auster, Favonius, Septentrio), but there are other eight subordinated ("non dubitamus, quod principales ventorum sint quattuor spiritus horumque suffraganei octo"). The circle of the world is surrounded by winds according to the divine order ("ordinatione divina et imperio Dei") and this is why wings are attributed to the heavenly spirits, so that their rapidity be suggested ("eorum instar ventorum celeritas"). The comparison between winds and virtues rests on the existence of two worlds: the physical world and the inner world of Spirit; each has its own "winds" and consistency: the physical world consists in Sky, Earth and See, whereas the spiritual world consists in charity, hope, and faith ("caritate, spe et fide"). Sky is the charity or love, as they seek upwards, earth is hope for harvest, that is, for the promise of God, and the see is faith, as they both suffer from storms of persecution. These are the three theological virtues ("spiritualibus tribus virtutibus"), of a pure kind ("incontaminatae"), on which Christ has grounded His Church.

The four cardinal virtues of the church established by the forerunners ("doctissimorum deliberatio perfectissima virorum") are prudence, fortitude, temperance, and justice ("prudentiam, fortitudinem, temperantiam et iustitiam" - see Etymologies, 2.24.5). Together with the theological virtues they create one single formation of seven spiritual virtues ("septem virtutum spiritualium"), which Gerard understands as seven spirits spreading over the Earth (according to John's Revelation 5.6), or as seven charismas given to the Church, according to Zachariah 4.2, Exodus 25.31. These seven charismas are interpreted as well as the six arms of the holy chandelier, made of the purest gold ever, with Christ in the middle. They enlighten, bring redemption, protect and save all humankind. According to the Revelation 37.17, these seven arms are tightly related: they spread together from Christ like arms, knots, cups, and lilies ("calami, spherulae, sciphi ac lilia procedunt").

Gerard says little about the four virtues, once more following the example of Isidore (Etymologies, 2.24.6) but still expresses his own descriptions. Prudence (prudentia), the first of them, rests on honesty and reason ("consideratione honestissima et ratione circa rationem amplectitur"); fortitude 
(fortitudo) is patience and suffering, temperance (temperantia) consists in control over flows and contempt of the world, and justice is to examine according to the highest truth and distribution according to tight measurement ("quae verissima examinatione et erogatione sensata astringitur"). Still, the four cardinal virtues surround the three theological virtues of the Church ("His nimirum ventis, id est spiritualibus virtutibus Christi ecclesia ... circumagitur" - Book VIII). Along with the seven, there are two other "winds" or spirits, namely, Aura et Altanus, that is, the contemplative and the active life, protecting the Church from every part ("quae ex omni parte ecclesiam reddidit munitam").

This interpretation results in rendering the cardinal virtues in a continuous system with theological ones, a part of a larger set of considerations regarding the relation between the mortal condition of humans and the heavenly stage of the redeemed. Continuity from cardinal to theological virtues is also necessary for the very reason that cardinal virtues should be able to allow one to praise God. This is something like a practical argument, sustained by authority. Thus, at the very beginning of Book I Gerard was comparing the human condition with the superior state of happiness: he refers to laus and superlaus, alternatively superexaltatio ("Laudare in saeculo, superexaltare in regno. Ergo hic laus, alibi superlaudatio, quemadmodum in utroque benedictio") as two different forms of praising God, both admitted but each specific to a different stage: laus is specific to human condition which takes place here, in the reign of tribulations ("tribulando igitur sancti laudant"), whereas superexaltatio refers to the superior post-life condition of laetitia. Gerard takes arguments of authority (ratio ex auctoritate) for the equivalence of the two, according to what appears to be his specific methodological practice: "Utrumque ut autem admittatur, ex utroque auctoritas loquatur", and: "saints praise while in tribulations, hyper-praise while being joyous" ("sancti tribulando laudant, laetando superexaltant" - Deliberatio, I).

This ratio ex auctoritate counts as practical proof rather than a logical argument as we would be inclined to consider, meaning rather something like an article of faith. It is the very key to understanding why Gerard puts together ancient philosophers and biblical quotations: philosophers can be confirmed by the articles of faith, and if so, then Gerard has a serious reason (practical ground, that is) to praise philosophers for their condition of being able to reach the divine truth, as reaching the divine truth is at its turn a practical proof for the efficiency of cardinal virtues.

\section{Conclusion}

Socrates is mentioned only once in the Deliberatio so the legitimate question why we paid so much attention to him in the title of our paper will be answered twofold. First, it is true that we cannot argue that Socrates presents much importance for Gerard. But it is the context which brings important contributions. Gerard takes for granted Isidore's suggestion that Socrates was responsible for giving the subject of cardinal virtues to philosophy, in their turn important for the development of the epicherematic discourse of Gerard. Second, the aim of this study was to investigate Gerard of Cenad's identification of the cardinal and theological virtues, as in István Bejczy's hypothesis. We reached the conclusion that there is rather unification than identification, that is, Gerard unifies the seven virtues into one system or formation of spiritual virtues that have been gifted to the Church. 


\section{References}

Barney, Stephen A., W. J. Lewis, J. A. Beach, Oliver Berghof. The Etymologies of Isidore of Seville. Cambridge: Cambridge University Press, 2006.

Batthyány, Ignatius. Sancti Gerardi episcopi Chanadiensis scripta et acta hactenus inedita cum serie episcoporum Chanadiensium. Albae-Carolinae, 1790.

Bejczy, István P. The Cardinal Virtues in the Middle Ages: A Study in Moral Thought from the Fourth to the Fourteenth Century. Leiden: Brill, 2011.

Lindberg, David C. The Beginnings of Western Science: The European Scientific Tradition in philosophical, Religious, and Institutional Context, Prehistory to A.D. 1450. Chicago: University of Chicago Press, 1992.

Luscombe, D. "The reception of the writings of Denis the pseudo-Areopagite", in Tradition and Change: Essays in Honour of Marjorie Chibnall, ed. D. Greenway, Ch. Holdsworth, J. Sayers, 115-144. Cambridge: Cambridge University Press, 1985.

Meyer, A. W. Critical and Exegetical Commentary on the New Testament. T. Clark, Funk \& Wagnalls, 1884.

Nemerkényi, Elöd. Latin Classics in Medieval Hungary $11^{\text {th }}$ Century. Budapest: Central European University Press, 2004.

Silagi, Gabriel. Gerard of Csanád. Deliberatio supra hymnum trium puerorum CCCM 49. Turnhout: Brepols, 1978.

Witt, Ronald G. The Two Latin Cultures and the Foundation of Renaissance Humanism in Medieval Italy. Cambridge: Cambridge University Press, 2012. 